\title{
First evidence of Equus asinus L. in the Chalcolithic disputes the Phoenicians as the first to introduce donkeys into the Iberian Peninsula
}

\author{
João L. Cardoso ${ }^{\mathrm{a}, *, 1}$, Julia T. Vilstrup ${ }^{\mathrm{b}, 1}$, Véra Eisenmann ${ }^{\mathrm{c}}$, Ludovic Orlando ${ }^{\mathrm{b}}$ \\ ${ }^{a}$ Universidade Aberta and Centro de Estudos Arqueológicos do Concelho de Oeiras (Câmara Municipal de Oeiras), Rua Silva Porto, 16, \\ Funchalinho, 2825-834 Trafaria, Portugal \\ ${ }^{\mathrm{b}}$ Centre for GeoGenetics, Natural History Museum of Denmark, University of Copenhagen, Oster Voldgade 5-7, 1350 Copenhagen K, Denmark \\ ${ }^{c}$ Département des Sciences de la Terre, Muséum national Histoire naturelle, Laboratoire de Paléontologie, 8, rue Buffon, 75005 Paris, France
}

\section{A R T I C L E I N F O}

\section{Article history:}

Received 27 May 2013

Received in revised form

7 July 2013

Accepted 8 July 2013

Keywords:

Equus asinus

Chalcolithic

Iberian Peninsula

\begin{abstract}
A B S T R A C T
Two equid species have been documented in the Pleistocene of the Iberian Peninsula, the horse Equus caballus, and the Eurasian hemione Equus hydruntinus. While the former survived the Holocene-Pleistocene until now, the timing for the extinction of the latter is unclear. Scarce, fragmented archaeological remains assess the presence of small equids living in the Holocene of Iberia. Those could possibly correspond to the Eurasian hemione although unambiguous morphological identification is often not possible. With the find of an equid tooth from Leceia, a Chalcolithic fortified site in Portugal, and using both morphological and mitochondrial genome analyses, we demonstrate for the first time the presence of a new equid species in Holocene Iberia, namely a donkey (Equus asinus). Radiocarbon dating of the tooth to Cal 2340-2130, and 2080-2060 BC with 95\% probability, demonstrates that donkeys were present in Iberia well before the arrival of Phoenicians in the first quarter of the first millennium BC (900 -750 years $\mathrm{BC}$ ), which were considered so far as the first who introduced donkeys in the region.
\end{abstract}

(ㄷ) 2013 Elsevier Ltd. All rights reserved.

\section{Introduction: the past presence of equids in the Iberian Península}

During the Late Pleistocene, the horse, Equus caballus is wellrepresented in the fossil record of the western part of the Iberian Peninsula. A geographic subspecies, Equus caballus antunesi (Cardoso and Eisenmann, 1989), mainly characterized by more slender metapodials than other wild horses of the same period, constitutes a significant part of the assemblages. This morphotype was characterised from limestone caves of the Portuguese Estremadura dated from 30,000 until almost 15,000 years BP (Cardoso, 1993, 1996) and constituted the source of post-Pleistocene wild horses from the Late Mesolithic shell-middens of Muge (Tagus valley).

The continuous presence of $E$. caballus in the Iberian peninsula (Morales Muñiz et al., 1998) is also attested from the Late Mesolithic

\footnotetext{
* Corresponding author. Tel.: +351913762560.

E-mail addresses: Cardoso18@netvisao.pt, joao.cardoso@uab.pt (J.L. Cardoso) juliavilstrup@gmail.com (J.T. Vilstrup), vera.eisenmann@orange.fr (V. Eisenmann), Lorlando@snm.ku.dk (L. Orlando).

1 These authors contributed equally to this study.
}

in the shell-middens of Muge, since the pioneer work of Francisco Pereira da Costa (Costa, 1865, Pl. 6, n. ${ }^{\circ} 6$ ), recently confirmed by Detry (2007) with scarce remains in the shell-middens of the Sado valley (Arnaud, 1987, p. 61) and in other sites of the same period in the Guadiana valley - Barca do Xerez de Baixo (Valente, 2008), and in the estremaduran region - Forno da Telha (Rowley-Conwy, 1993) to the Chalcolithic, with unambiguous first phalanx biometric measurements at several sites (Cardoso, 1995a), well known idols with a natural anthropomorphic shape engraved in horse first phalanxes, and alimentation remnants found in settlements.

Besides E. caballus, a small equid is recorded in the Late Pleistocene of Portugal and more generally, all over southern Europe. Morphological features identified in the upper cheek teeth found in one karstic cave near Lisboa, Pedreira das Salemas, assigned them to Equus hydruntinus (Cardoso, 1995b). This presently extinct species was never domesticated and reached the Crimea and Iran, where it was known until the Iron Age (Orlando et al., 2006). It is disputable however whether it survived until the Chalcolithic in the Iberian Peninsula, where scarce, fragmented remains often preclude unambiguous diagnosis. In fact, the bone material attributed to E. hydruntinus of some Chalcolithic settlements of the southern part of the 
peninsula (Uerpmann, 1976) returned a Medieval radiocarbon age, post-dating the global extinction time for this species, and consequently were revised to donkey (Equus asinus) (Von den Driesch, 2000). This does not necessarily imply that all material identified as E. hydruntinus by Uerpmann belong to domestic donkey of historical times. In fact, A. v. d. Driesch admits that some pieces may belong to this species, like one calcaneum from Cueva de Carigüela, which was found in a layer under dated horse bones, suggesting that this species was still alive in the Iberian Peninsula at the beginning of the 5th millennium BC. H.-P. Uerpmann omits the occurrences of some pieces of this or other similar small non-caballine equids in some Chalcolithic Portuguese settlements: as is the case of the fortified sites of Vila Nova de S. Pedro, Azambuja, Lisbon District, where H. Breuil had identified, besides E. caballus, rare remains of an asinine (Jalhay and Paço, 1945), and Monte da Tumba, eventually attributed to E. hydruntinus (Antunes, 1987).

The time of extinction of E. hydruntinus in the Iberian Peninsula has also been a matter of debate. For some authors, the Portuguese name "zebro" or "zebra", equivalent to the Spanish name "encebro" could correspond to E. hydruntinus; the presence of a wild equid in the Iberian Peninsula is registered both in medieval documents from the 12-16th century, as well as in toponymy (Nores and Liesau, 1992; Antunes, 2006). Quoting the geographical distribution of the references to this animal, both authors presented a map which shows the last reference is in the southeast, a semi-arid region where the species survived until its extinction. In fact, the leather was very appreciated for shoes (Oliveira de Oliveira Marques, 1987; p. 28, 51, 225) and even for the manufacture of shields for war (Antunes, 2006), supporting venatory activities, and also to prevent the destruction of crops by this herd living animal. The correlation between E. hydruntinus and the "zebro", though attractive, has been rejected by ancient DNA analyses that assigned the remains purported to have been the last representative of this species, to donkeys (Orlando et al., 2009). Therefore, the "zebro" were most likely domestic donkeys (E. asinus) turned feral, a possibility proposed by C. Liesau, during several stages of the historic record, related to epidemic diseases, which conduced to the abandonment of the fields (pers. comm., 5 March 2013).

\section{The findings of the Chalcolithic fortified site of Leceia, Oeiras, Lisbon district}

\subsection{General archaeological characteristics of the settlement}

The fortified site of Leceia is situated in the top of the right slope of the Barcarena valley, about $4 \mathrm{~km}$ from the confluence with the Tagus estuary. During the 20 years of excavations, it was defined as a large and complex defensive system, occupying about $11,000 \mathrm{~m}^{2}$, organized in three successive defensive lines, and articulated with the local topography, delimited in space by the two other sides corresponding to an escarpment of cretaceous recifal limestones. It was possible to relate the stratigraphical sequence with the described cultural expression through the successive constructional phases that were identified, and with the absolute chronology obtained for the sequence (Cardoso, 2000, 2008, 2011). The results may be summarized as follows:

- Layer 2 = Third Cultural Phase (Full/Late Chalcolithic of the Estremadura $)=$ Fifth Constructive Phase, second half of the third millennium $\mathrm{BC}$;

- Layer 3 = Second Cultural phase (Early Chalcolithic of the Estremadura) $=$ Second to Fourth Constructive Phases, circa 2800/2900-2600/2500 cal BC;
- Layer $4=$ First Cultural Phase (Late Neolithic of the Estremadura $)=$ First Constructive Phase $=$ second half of the fourth millennium to the beginning of the third millennium BC.

The first prehistoric occupation is represented by the building structures of purely habitational nature, which belong to the First Phase of Construction. The following constructive phases show that there was an organized and preconceived occupation of the space with the erection, in a single stroke in the Second Constructive Phase, of a complex fortification. The internal coherence of the restorations and changes themselves, made during the two following constructive phases, still within the Initial Chalcolithic, confirm that evidence. The placing of the constructions shows that there were preoccupations of a proto-urban nature. There are paths, some paved and others not, with steps in one of them to surmount the southern slope of the settlement, and paths that serve as main lines of communication, both within and outside the fortified space. There is also a large intra-mural open-air area paved with stone slabs for people and goods to be gathered into, perhaps in times of conflict. In the Full Chalcolithic, the decadence of the building effort is evident. In this cultural phase the buildings are almost exclusively dwellings. In many instances the fortification walls have already been abandoned and, in some places, even ruined.

\subsection{The archaeological context and the absolute chronology}

It is in one context of the Full Chalcolithic that, during the 2002 campaign, an equid tooth was collected, the main object of this study. The finding is situated in the exterior of the EX Bastion (Fig. 1), a structure connected to the first defensive line of the fortification (Fig. 2). Due to the scarcity of equid remains in the settlement and, even more so, of small equids, some of them were selected for radiocarbon analysis by AMS, but only the piece in question is contemporaneous with the last occupation of the site (Full/Late Chalcolithic: Beta $-260293-3790 \pm 40 \mathrm{BP}$, or 23402130 and 2080-2060 cal BC, with 95\% probability, by using INTCAL 04 Radiocarbon Age Calibration (Radiocarbon, Vol. 46, nr. 3, 2004).

In fact, there are some limb bones (phalanxes) and several teeth of horse (E. caballus) from Leceia, but all of the ones that were analysed by the radiocarbon AMS method were more modern than the Chalcolithic occupation of the site, which is consistent with the historical record of the site, that it was occupied for farming activities during medieval and modern times.

\subsection{Morphology and biometry}

The tooth, a left $\mathrm{M} / 3$, is incomplete along the distal border, presents medium wear, and is characterised by its small dimensions, which immediately suggests a non-caballine equid (Fig. 3). In fact, the DMD (length, longitudinal diameter), although incomplete, would not be greater than $20 \mathrm{~mm}$, and the DMD (breadth, transversal diameter), is $12 \mathrm{~mm}$. The morphology of the enamel folds confirms it as an asinine, and the small ectoflexid, which does not penetrate into the double knot, excludes E. hydruntinus. This analysis revealed the possible presence of a new wild or domestic asinine, possibly the donkey, in the second part of the third millennium in the occident of Iberia. This finding contradicts current models suggesting that donkeys have been introduced by the Phoenicians in the first quarter of the first millennium BC (900-750 years BC), along the littoral establishments, from which the species spread out occupying soon after all of the Iberian Peninsula, before the roman conquest (Altuna, 1980; Altuna and Mariezkurrena, 1986; Pereira et al., 2006). We therefore decided 


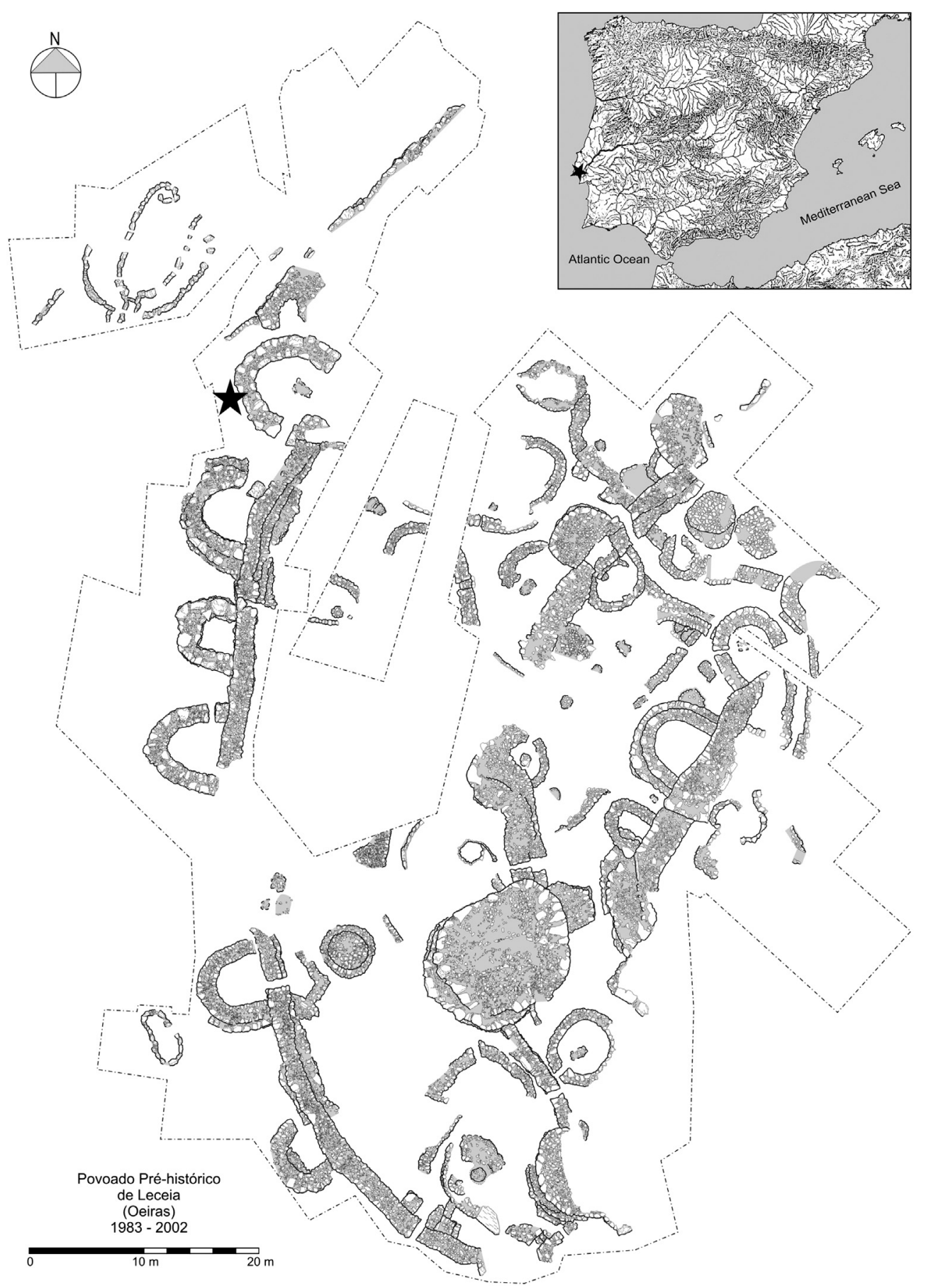

Fig. 1. General plan of the fortified settlement of Leceia; the location of the finding is signalled by a star. After J. L. Cardoso.

to confirm the taxonomic status of the tooth by ancient DNA molecular analyses.

\subsection{Molecular analyses}

\subsubsection{DNA extraction, amplification and sequencing}

We drilled and extracted the tooth sample which we named P2_Leceia (415 mg) and for comparison a second tooth P1_Porto (a left $\mathrm{M} / 2$ collected from Porto das Carretas, a Chalcolithic site in the south of Portugal, near the Guadiana river, and dated to around the same time as the Leceia sample, the second half of the third millennium BC) 185-332 mg were obtained from three extractions by a silica-based extraction protocol as in Orlando et al. (2009) with appropriate extraction controls in an ancient DNA laboratory at the Centre for GeoGenetics, Copenhagen, Denmark. We then built the DNA extractions into indexed blunt-end libraries using the NEBNext DNA Library Prep Master Mix set for 454 (Biolabs, ref:E6070s) and amplified the libraries as in Vilstrup et al. (2013). The first $50 \mu \mathrm{l}$ PCR amplification consisted of 8-10 cycles and included the full $25 \mu$ DNA library, while the second consisted of four parallel PCRs consisting of $5 \mu \mathrm{l}$ library each amplified for 10-12 cycles and purified on the same MinElute column. Half of the best amplified and purified libraries were directly shotgun sequenced on Illumina HiSeq2000 and the other half was capture enriched individually 


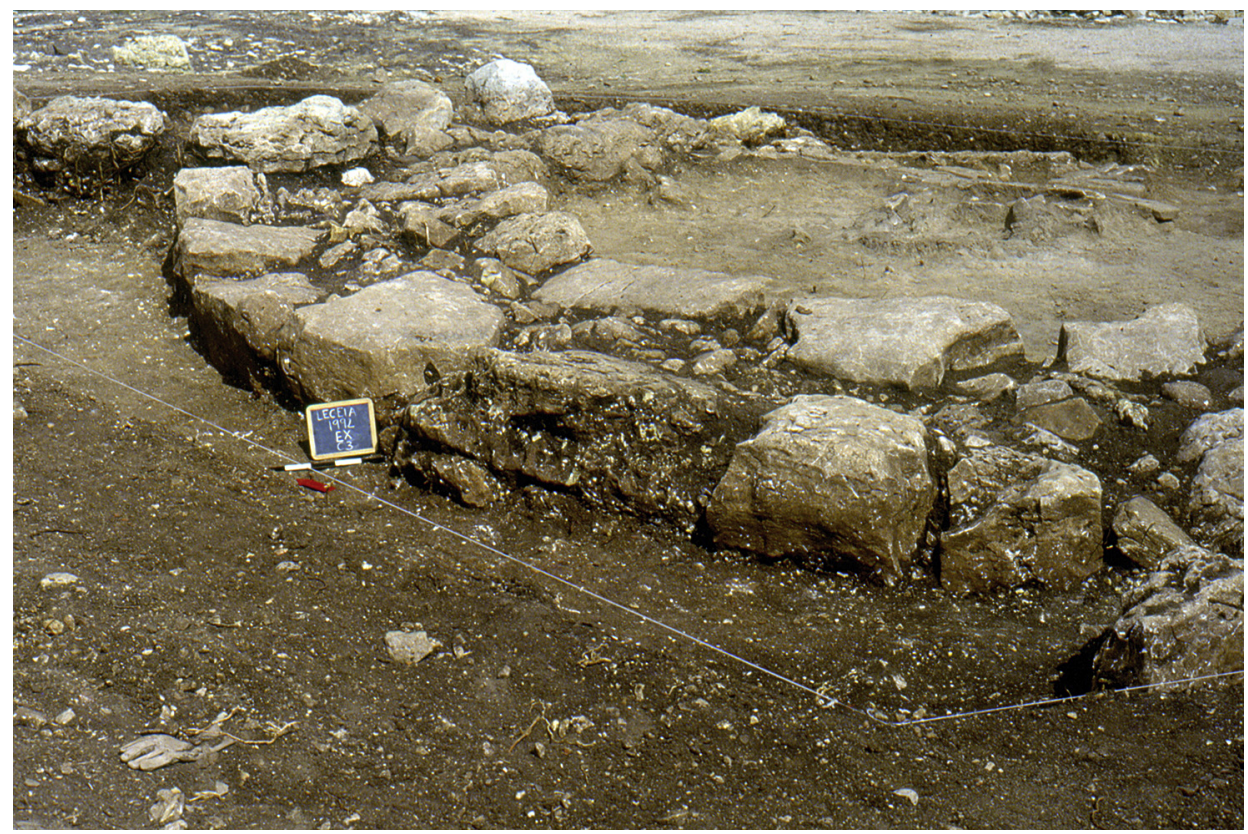

Fig. 2. External view of the Bastion EX, corresponding to the location of the finding. Photo by J. L. Cardoso.

with a blank using BioT/B adapted baits as in Vilstrup et al. (2013). Post capture, the samples were amplified by two consecutive PCRs, the first 15 cycles in a $50 \mu$ amplification followed by 8 cycles of three parallel $25 \mu \mathrm{l}$ PCRs in the second amplification, purified on the same column using the same PCR conditions as in Vilstrup et al. (2013). The captured libraries were pooled in equimolar ratios together with other indexed samples on 1 lane on a Hiseq2000 sequencing platform (Illumina).

We trimmed our reads using a minimal read length of $25 \mathrm{bp}$ in AdapterRemoval (Lindgreen, 2012) and mapped them against full mitochondrial equid genomes (Vilstrup et al., 2013) using BWA (Li and Durbin, 2009), disabling the seed and relaxing the edit distance
(Schubert et al., 2012). Reads that mapped to multiple positions and which had a mapping quality score $<25$ were discarded using SAMtools (Li et al., 2009). Finally, we removed sequence duplicates using MarkDuplicates from the Picard package (http://picard. sourceforge.net). Final alignments were visually corrected for potential local misalignments and the final sequence was called using a minimum base coverage of 2 and over 50\% sequence match among reads.

\subsubsection{Phylogenetic and topological analyses}

We partitioned the protein coding genes of the mitogenomes into first, second and third codon positions using Stothard's (2000)

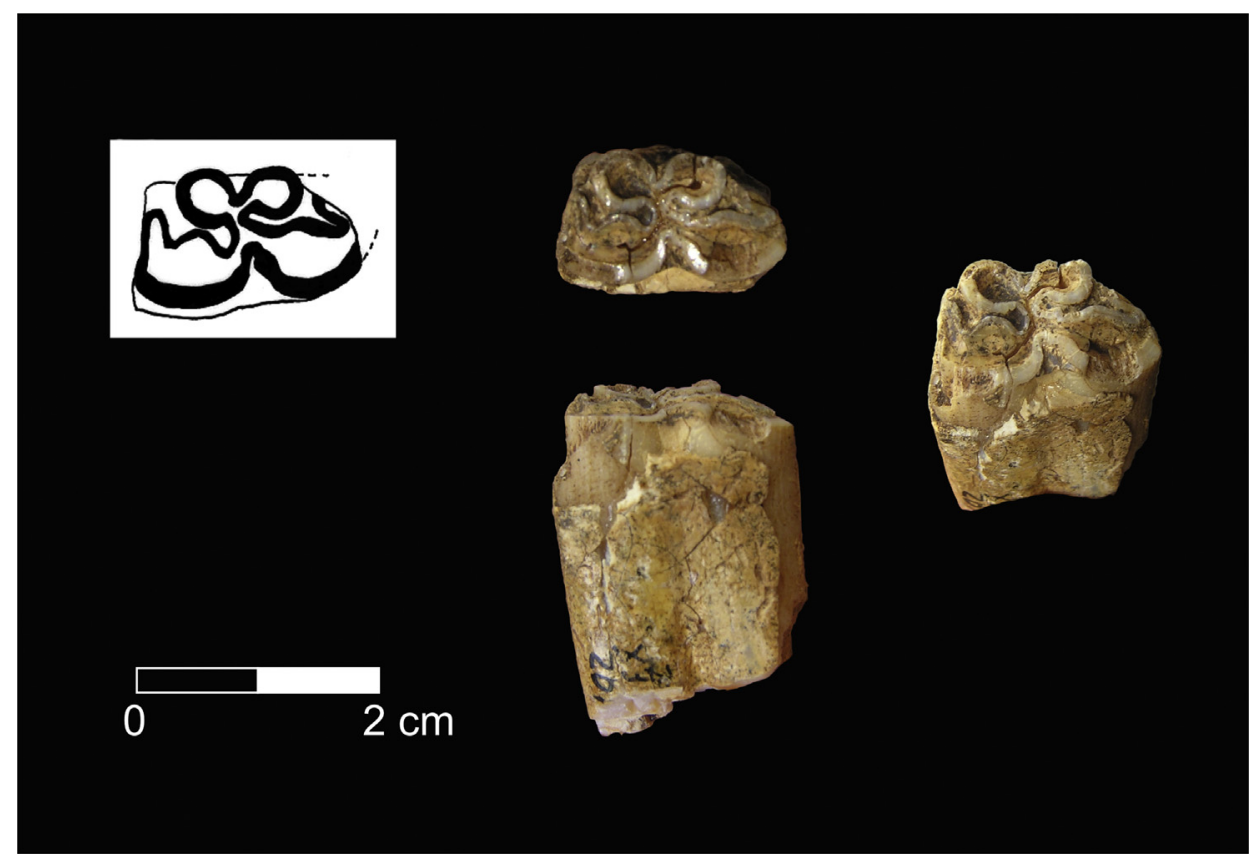

Fig. 3. M/3 of Equus asinus of Leceia: morphology of the enamel in occlusal view and different views of the same exemplar. Drawn by B. L. Ferreira; photos by J. L. Cardoso. 
online Sequence Manipulation Suite, with the RNAs and control region making up the fourth and fifth partition. We ran jModelTest v0.1 (Posada, 2008) with corrected AIC to compute the most suitable substitution model for the 5-partitioned data set, unpartitioned and per partition. Outgroup taxa representing all living equids as well as three extinct lineages (Vilstrup et al., 2013) were included in all phylogenetic analyses.

We computed maximum likelihood analyses on the 5partitioned data set using 500 thorough bootstraps and the GTR + G model in RAxML GUI 1.0 (Silvestro and Michalak, 2012). We also ran Bayesian phylogenetic inference analyses in BEAST (Drummond and Rambaut, 2007) using 300 million iterations on the 5-partitioned data set with different substitution models for each partition as computed from jModelTest. Monophyly was constrained for species with multiple individuals and the zebra clade, and we ran separate analyses with Birth and Deaths, and the Yule speciation model. Finally, we compared the control region sequence characterized in the P2_leceia sample to the variety of haplotypes characterized in extant and ancient donkey specimens (Table 1), using median-joining haplotype network reconstruction using NETWORK v4.6 (http://www.fluxux-engineering.com; Bandelt et al., 1999; Forster et al., 2001; Polzin and Daneschmand, 2003) with weights between 5 and 15, using star contraction and MP correction, and epsilon $=10$.

\subsubsection{Results of the molecular analyses}

We sequenced the near complete mitochondrial genome $(13,749 \mathrm{bp})$ of sample P2_Leceia with an average coverage of $23.46 \times(2-178 \times)$. A total of 1545 bp of the P1_Porto sample, contemporary with P2_Leceia sample, was generated for comparison. Maximum support from both Maximum Likelihood and Bayesian analyses (Fig. 4) confirm the P2_Leceia sample is a donkey (E. asinus) and P1_Porto is a horse (E. caballus). The absence of a 28 bp deletion in the control region further rejects the Leceia sample as a hemione. Finally, a haplotype network of control region sequences from Somali and Nubian wild asses and contemporary donkeys show that the P2_Leceia sample clusters with domestic donkeys and Nubian wild asses as opposed to Somali wild ass sequences (Fig. 5).

\section{Discussion}

We note that it is not a requirement to sequence the complete mitogenome in order to distinguish between equids at the species level. A short segment of the hypervariable region containing the 28 bp deletion seen in E. hydruntinus, E. hemionus and E. kiang provide a diagnostic barcode for species identification of fossil equids (Orlando et al., 2009). However, capture-based data can provide additional information regarding the DNA damage levels of an ancient DNA extract and could help authenticating genetic data (Ginolhac et al., 2011; Jónsson et al., 2013). Therefore, it is used as a standard procedure at the Centre for GeoGenetics in Copenhagen in order to screen archeological findings for further genetic analyses. Nonetheless, the morphological and molecular analyses (Figs. 3-5) confirm with maximum support that the Leceia tooth did not originate from E. caballus or E. hydruntinus, the only two equid species known in the Pleistocene in the Iberian Peninsula. Instead, the mitochondrial genome ascribes the Leceia tooth to E. asinus, a donkey, suggesting a new species of equid was present in Chalcolithic Iberia. The Porto sample, of similar age, included for comparison is from E. caballus (Fig. 4). More specifically the Leceia sample clusters together with the domestic donkey E. asinus and the now extinct Nubian wild ass, Equus africanus africanus (Geigl and Grange, 2012) (Fig. 5). Thus, based on the mitochondrial genome analyses, the Leceia sample could belong to either a
Table 1

Control region sequences used in haplotype network.

\begin{tabular}{|c|c|c|}
\hline Sample name & Genbank ID & Reference \\
\hline Ea_YN01F4 & AF531462 & Lei et al., 2007 \\
\hline Ea_XJ02F3 & AF532120 & Lei et al., 2007 \\
\hline Ea_LZ2F5 & AF532125 & Lei et al., 2007 \\
\hline Ea_GZ02F6 & AF532126 & Lei et al., 2007 \\
\hline Eas_AP012271 & AP012271 & Goto et al., 2011 \\
\hline Ea_ER04 & AY569465 & Beja-Pereira et al., 2004 \\
\hline Ea_RU01 & AY569471 & Beja-Pereira et al., 2004 \\
\hline Ea_AL17 & AY569473 & Beja-Pereira et al., 2004 \\
\hline Ea_AS01 & AY569477 & Beja-Pereira et al., 2004 \\
\hline Ea_AZ01 & AY569484 & Beja-Pereira et al., 2004 \\
\hline Ea_BE10 & AY569485 & Beja-Pereira et al., 2004 \\
\hline Ea_BF07 & AY569487 & Beja-Pereira et al., 2004 \\
\hline Ea_CHO2 & AY569493 & Beja-Pereira et al., 2004 \\
\hline Ea_HU07 & AY569499 & Beja-Pereira et al., 2004 \\
\hline Ea_KE01 & AY569503 & Beja-Pereira et al., 2004 \\
\hline Ea_KO03 & AY569504 & Beja-Pereira et al., 2004 \\
\hline Ea_LI05 & AY569505 & Beja-Pereira et al., 2004 \\
\hline Ea_MA01 & AY569507 & Beja-Pereira et al., 2004 \\
\hline Ea_ML01 & AY569509 & Beja-Pereira et al., 2004 \\
\hline Ea_MO01 & AY569511 & Beja-Pereira et al., 2004 \\
\hline Ea_R017 & AY569517 & Beja-Pereira et al., 2004 \\
\hline Ea_SA11 & AY569519 & Beja-Pereira et al., 2004 \\
\hline Ea_SPi3 & AY569522 & Beja-Pereira et al., 2004 \\
\hline Ea_SU01 & AY569523 & Beja-Pereira et al., 2004 \\
\hline Ea_TK26 & AY569527 & Beja-Pereira et al., 2004 \\
\hline Ea_UE34 & AY569528 & Beja-Pereira et al., 2004 \\
\hline Ea_CR02 & AY569531 & Beja-Pereira et al., 2004 \\
\hline Ea_GH08 & AY569532 & Beja-Pereira et al., 2004 \\
\hline Ea_EG36 & AY569534 & Beja-Pereira et al., 2004 \\
\hline Ea_ET10 & AY569536 & Beja-Pereira et al., 2004 \\
\hline Ea_H6 & AY569543 & Beja-Pereira et al., 2004 \\
\hline Ea_H7 & AY569544 & Beja-Pereira et al., 2004 \\
\hline Eas_H8 & AY569545 & Beja-Pereira et al., 2004 \\
\hline Eas_H9 & AY569546 & Beja-Pereira et al., 2004 \\
\hline Eas_H10 & AY569547 & Beja-Pereira et al., 2004 \\
\hline Ea_JMS8 & AY666167 & Lei et al., 2007 \\
\hline Ea_JMS26 & AY666168 & Lei et al., 2007 \\
\hline Ea_JM14 & DQ368536 & Lei et al., 2007 \\
\hline Ea_JM80 & DQ368538 & Lei et al., 2007 \\
\hline Ea_MG16 & DQ368560 & Lei et al., 2007 \\
\hline Ea_MG25 & DQ368562 & Lei et al., 2007 \\
\hline Ea_QY14 & DQ368573 & Lei et al., 2007 \\
\hline Ea_TH31 & DQ368585 & Lei et al., 2007 \\
\hline Ea_YPGZ58 & DQ448935 & Chen et al., 2006 \\
\hline Ea_YPXZ02 & DQ449009 & Chen et al., 2006 \\
\hline Ea_YPXZ14 & DQ449021 & Chen et al., 2006 \\
\hline Eaa_PCM54 & HM622629 & Kimura et al., 2011 \\
\hline Eas_NHML1886 & HM622631 & Kimura et al., 2011 \\
\hline Eaa_NHML1904 & HM622632 & Kimura et al., 2011 \\
\hline Eaa_BSZM1952 & HM622634 & Kimura et al., 2011 \\
\hline Eaa_BSZM1963 & HM622635 & Kimura et al., 2011 \\
\hline Eaa_RMCA31155 & HM622636 & Kimura et al., 2011 \\
\hline Eas_WA6 & HM622641 & Kimura et al., 2011 \\
\hline Eas_WA7 & HM622642 & Kimura et al., 2011 \\
\hline Eas_WA21 & HM622653 & Kimura et al., 2011 \\
\hline Eas_WD6 & HM622659 & Kimura et al., 2011 \\
\hline Eas_WD8 & HM622660 & Kimura et al., 2011 \\
\hline Eas_WD12 & HM622663 & Kimura et al., 2011 \\
\hline Eas_ErA4 & HM622668 & Kimura et al., 2011 \\
\hline Ea_X97337 & X97337 & Xu et al., 1996 \\
\hline Ea_P2_Leceia & XXXXXXXX & This study \\
\hline
\end{tabular}

$\overline{\mathrm{Ea}}=$ Equus asinus, Eaa $=$ Equus africanus africanus, Eas = Equus africanus somaliensis.

domestic or wild donkey. Studies using mitochondrial DNA suggests that domesticated donkeys originated primarily from the extinct Nubian wild ass and ancestors of the extant Somali wild ass (Kimura et al., 2011; Rossel et al., 2008). The radiocarbon date obtained for the Leceia tooth rejects the first introduction to the Iberian Peninsula by the Phoenicians in the 8-9th century BC. As donkeys were domesticated in northeast Africa or/and potentially the Middle East around 5000 years ago (Beja-Pereira et al., 2004), more than 750 years before the age of the Leceia tooth, our sample 


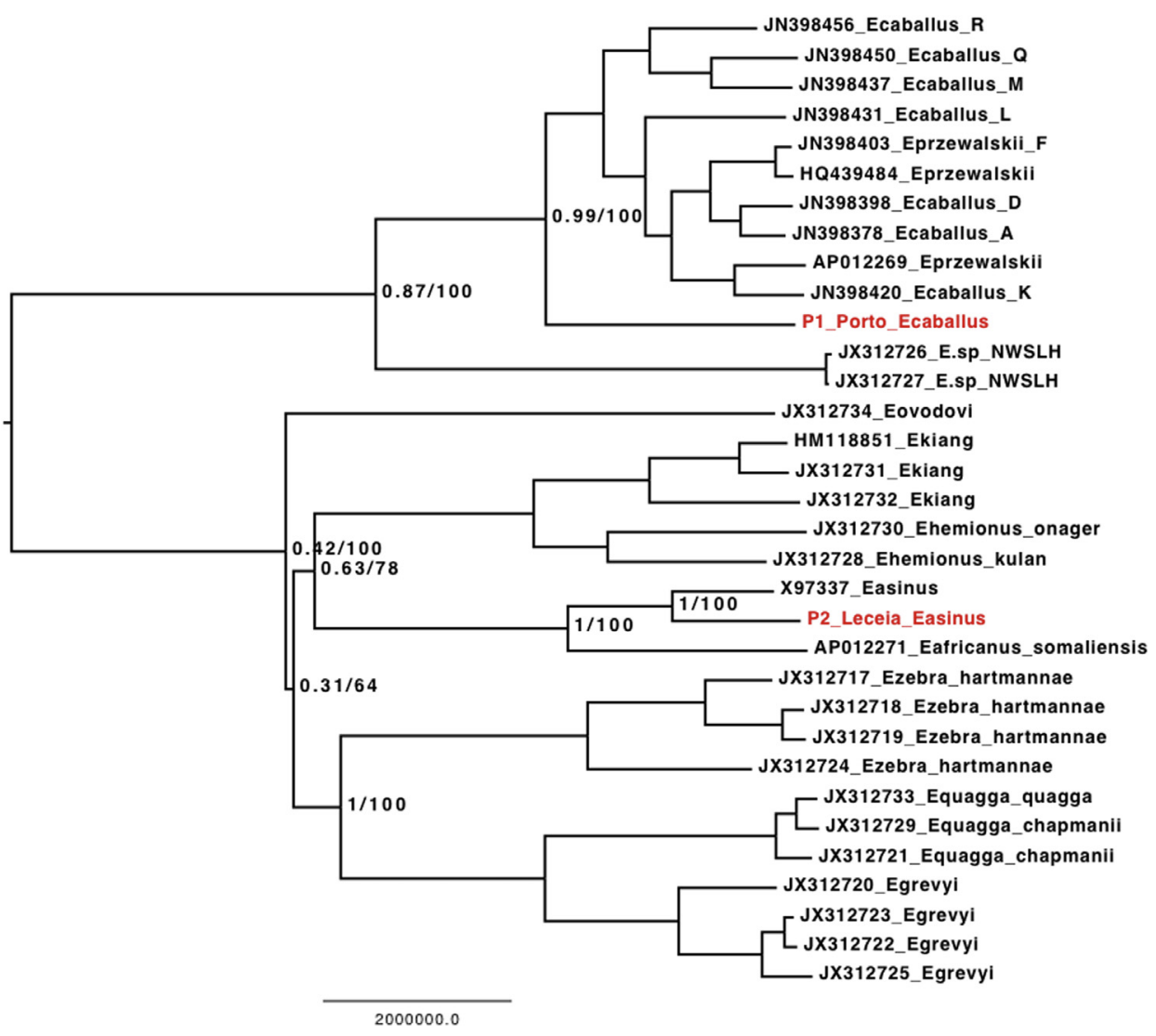

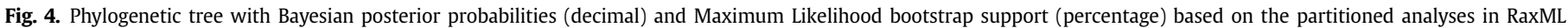
$(\mathrm{GTR}+\mathrm{G})$ and BEAST.

could equally represent a wild individual, or a donkey from the early domestication process. The hypothesis that this piece represents a trophy or a symbolic artefact is not confirmed by the presence of use wear, or any morphological modification in their shape or transformation of their surface.

In general, based on bone measurements, larger sized specimens are attributed to wild asses and smaller individuals to domestic (Rossel et al., 2008), however size cannot be deduced from teeth samples. Kimura et al. (2011) also found little mitochondrial genetic diversity between wild and domestic donkeys and put this down to wild individuals still being present during the domestication process, something also defined in dogs, deer, pigs and horses. This also proposed that the domestication process continued over a prolonged time with new wild recruitments (Kimura et al., 2011; Rossel et al., 2008).

Significant amount of ivory artefacts from elephant tusks are found in a wide variety of archeological sites in South Portugal (Schuhmacher et al., 2009; Schuhmacher and Banerjee, 2012), including the settlement of Leceia. This trade (Schuhmacher et al., 2009; Cardoso and Schuhmacher, 2012), particularly evident

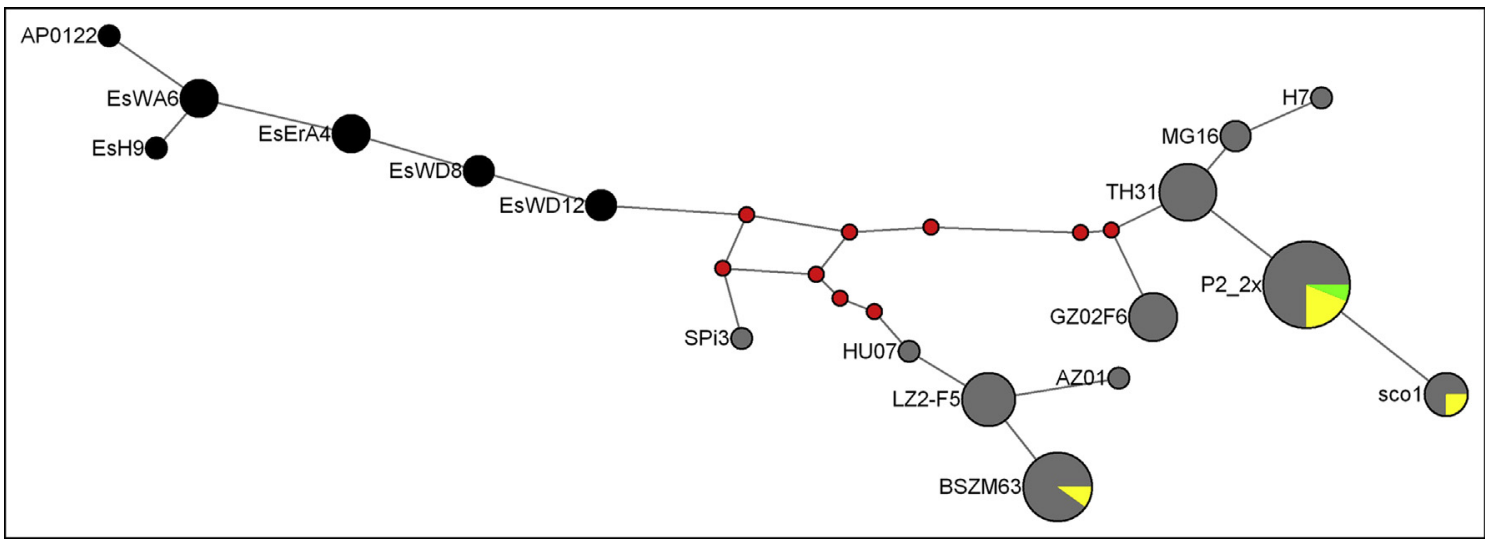

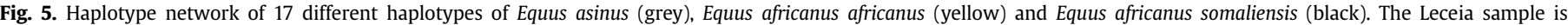

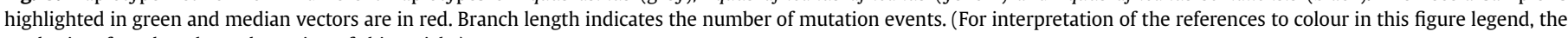
reader is referred to the web version of this article.) 
since the first half of the third millennium BC, with the occurrence in the second half of this millennium of bell beakers, Palmela points, and tonged copper daggers in the Moroccan territory (Harrison and Gilman, 1977; Poyato Holgado and Hernando Grande, 1988; Bokbot, 2005), could be accompanied by the introduction from Northern Africa of other products, like domestic donkeys. Alternatively, should the Chalcolithic ivory pieces be of an Asian elephant (Elephas maximus) origin that other trade routes than the North African one could have resulted in the introduction of the domestic donkey in Iberia.

\section{Conclusions}

In this study, we combine morphological and molecular analyses and demonstrate the presence of a donkey, E. asinus, in the second half of the third millennium BC in Iberia, which could be a domestic descendant of the now extinct Nubian wild ass (E. africanus africanus). We dismiss our Leceia donkey as from the Phoenician introduction of domestic donkeys in the 8-9th century BC. The earlier introduction of this species in the Iberian Peninsula could possibly be related to the ivory trade between North Africa and Iberia during the Chalcolithic. Our findings suggest that domestic donkeys were introduced into the Iberian Peninsula approximately 1500 years earlier than previously considered.

\section{Author contributions}

JLC conceived the study, collected the samples, and performed the archaeological and chronological discussion, JTV and LO performed the molecular experiments and phylogenetic analyses; LO contributed material, reagents, and methods; VE conducted the morphological analyses; JLC and JTV wrote the paper, with significant input from VE and LO.

\section{Acknowledgements}

We thank Tina Brand and the laboratory technicians at the Danish High-throughput DNA Sequencing Centre for technical assistance; Corina Liesau, Mikkel Schubert and Aurelien Ginolhac for computational assistance; Ruth Garcia-Fernandez, Clio der Sarkissian and Luca Ermini for fruitful discussion and valuable input in earlier versions of the present manuscript. This work was supported by the Danish Council for Independent Research, Natural Sciences (FNU); the Danish National Research Foundation; a MarieCurie Career Integration Grant (FP7 CIG-293845) and the Municipality of Oeiras (Oeiras, Portugal).

\section{References}

Altuna, J., 1980. History of animal domestication in the Basque country Spain from its origins until its conquest by the Romans. Munibe 32 (1-2), 9-163.

Altuna, J., Mariezkurrena, K., 1986. Introduction de l'Âne (Equus Asinus) au Pays Basque. Archaeozoologia Mélanges, Grenoble, pp. 125-130.

Antunes, M.T., 1987. O povoado fortificado do Calcolítico do Monte da Tumba. IV Mamíferos (nota preliminar). Setúbal Arqueológica 8, 103-144.

Antunes, M.T., 2006. The Zebro (Equidae) and its extinction in Portugal, with an Appendix on the noun zebro and the modern "zebra". In: Mashkour, M. (Ed.) Equids in Time and Space. Papers in Honour of Véra Eisenmann. Oxbow Books pp. $210-235$.

Arnaud, J.M., 1987. Os concheiros mesolíticos dos vales do Tejo e do Sado: semelhanças e diferenças. Arqueologia 15, 53-64.

Bandelt, H.-J., Forster, P., Röhl, A., 1999. Median-joining networks for inferring intraspecific phylogenies. Mol. Biol. Evol. 16, 37-48

Beja-Pereira, A., England, P.R., Ferrand, N., Jordan, S., Bakhiet, A.O., Abdalla, M.A Mashkour, M., Jordana, J., Taberlet, P., Luikart, G., 2004. African origins of the domestic donkey. Science 304 (5678), 1781

Bokbot, Y., 2005. La civilización del vaso Campaniforme en Marruecos y la cuestión del sustrato Calcolíco precampaniforme. In: Rojo-Guerra, M., Garrido-Pena, R., García-Martínez de Lagrán, I. (Eds.), El campaniforme en la Península Ibérica y su contexto europeo, pp. 137-173. Valladolid.
Cardoso, J.L., 1993. Contribuição para o conhecimento dos grandes mamíferos do Plistocénico superior de Portugal. Câmara Municipal de Oeiras, Oeiras.

Cardoso, J.L., 1995a. Os ídolos-falange do povoado pré-histórico de Leceia (Oeiras). Estudo comparado. Estudos Arqueológicos de Oeiras 5, 213-232.

Cardoso, J.L., 1995b. Presença de Equus hydruntinus Regalia, 1905 no Würm recente de Portugal. Comunicações do Instituto Geológico e Mineiro 81, 97-108.

Cardoso, J.L., 1996. Les grand mammifères du Péistocène supérieur du Portugal. Essai desynthèse. Geobios 29 (2), 235-250.

Cardoso, J.L., 2000. The fortified site of Leceia (Oeiras) in the context of the Chalcolithic in Portuguese Estremadura. Oxf. J. Archaeol. 19 (1), 37-55.

Cardoso, J.L., 2008. The Chalcolithic fortified site of Leceia (Oeiras, Portugal). Verdolay $11,49-66$.

Cardoso, J.L., 2011. The prehistoric settlement of Leceia (Oeiras, Portugal). Results of the excavations of 1983-2002. Suppl. Archaeological J. 168, 42-51.

Cardoso, J.L., Eisenmann, V., 1989. Equus caballus antunesi, nouvelle sous-espèce quaternaire du Portugal. Palaeovertebrata 19 (2), 47-72.

Cardoso, J.L., Schuhmacher, T.X., 2012. Marfiles calcolíticos en Portugal. Estado de la cuestión. In: Banerjee, A., López Padilla, J.A., Schuhmacher, T.X. (Eds.), Elfenbeinstudien, Faszikel 1: Marfil y elefantes en la Península Ibérica y el Mediterráneo occidental. Verlag Philipp von Zabern, Darmstadt/Mainz, pp. 95-110.

Chen, S.Y., Zhou, F., Xiao, H., Sha, T., Wu, S.F., Zhang, Y.P., 2006. Mitochondrial DNA diversity and population structure of four Chinese donkey breeds. Anim. Genet. 37 (4), 427-429.

Costa, F.L. Pereira da, 1865. Da existência do Homem em epochas remotas no valle do Tejo. Primeiro opúsculo. Noticia sobre os esqueletos humanos descobertos no Cabeço da Arruda. Commissão Geologica de Portugal, Lisboa.

de Oliveira Marques, A.H., 1987. A Sociedade Medieval Portuguesa, 5.a edição. Livraria Sá da Costa Editora, Lisboa.

Detry, C., 2007. Paleoecologia e paleoeconomia do baixo Tejo no Mesolítico Final: o contributo do estudo dos mamíferos de Muge. Universidade de Salamanca/ Universidade Autónola de Lisboa, Salamanca/Lisboa (unpublished PhD thesis).

Drummond, A.J., Rambaut, A., 2007. BEAST: Bayesian evolutionary analysis by sampling trees. BMC Evol. Biol. 7, 214.

Forster, P., Torroni, A., Renfrew, C., Röhl, A., 2001. Phylogenetic star contraction applied to Asian and Papuan mtDNA evolution. Mol. Biol. Evol. 18, 1864-1881.

Geigl, E.-M., Grange, T., 2012. Eurasian wild asses in time and space: morphological versus genetic diversity. Ann. Anat. 194 (1), 88-102.

Ginolhac, A., Rasmussen, M., Gilbert, M.T., Willerslev, E., Orlando, L., 2011. mapDamage: testing for damage patterns in ancient DNA sequences. Bioinformatics 27 (15), 2153-2155.

Goto, H., Ryder, O.A Fisher A.R. Schultz, B., Pond, S.L.K, Nekrutenko, A, Makova, K.D., 2011. A massively parallel sequencing approach uncovers ancient origins and high genetic variability of endangered przewalski's horses. Genome Biol. Evol. 3, 1096-1106.

Harrison, R.J., Gilman, A., 1977. Trade in the Second and Third Millennia B.C. between the Maghreb and Iberia. In: Markotic, V. (Ed.), Ancient Europe and the Mediterranean, Studies in Honour of Hugh Hencken, pp. 90-104. Warminster.

Jalhay, E. Paço, A. do, 1945. El castro de Vilanova de San Pedro. Actas y Memorias de la Sociedad Española de Antropología, Etnografía y Prehistoria 20, 55-141.

Jónsson, H., Ginolhac, A., Schubert, M., Johnson, P., Orlando, L., 2013. mapDamage2.0: fast approximate Bayesian estimates of ancient DNA damage parameters. Bioinformatics 29 (13), 1682-1684.

Kimura, K., Marshall, F.B., Chen, S., Rosenbom, S., Moehlman, P.D., Tuross, N., Sabin, R.C., Peters, J., Barich, B., Yohannes, H., et al., 2011. Ancient DNA from Nubian and Somali wild ass provides insight into donkey ancestry and domestication. Proc. R. Soc. B 287, 50-57.

Lei, C.-Z., Ge, Q.-L., Zhang, H.-C., Liu, R.-Y., Zhang, W., Jiang, Y.-Q., Dang, R.-H., Zheng, H.-L., Hou, W.-T., Chen, H., 2007. African maternal origin and genetic diversity of Chinese domestic donkeys. Asian-Aust J. Anim. Sci. 20 (5), 645-652.

Li, H., Durbin, R., 2009. Fast and accurate short read alignment with BurrowsWheeler transform. Bioinformatics 25, 1754-1760.

Li, H., Handsaker, B., Wwysoker, A., Fennell, T., Ruan, J., et al., 2009. The sequence alignment/map format and SAMtools. Bioinformatics 25, 2078-2079.

Lindgreen, S., 2012. AdapterRemoval: easy cleaning of next generation sequencing reads. BMC Res. Notes 5, 337.

Morales Muñiz, A., Albertini, D., Sancho, F.B., Cardoso, J.L., Castaños, P.M., Liesau von Lettow - Vorbeck, C., Montero-Ponseti, S., Nadal Lorenzo, J., Nicolás Pérez, E., Pérez Ripoll, M., Pino Uria, B., Riquelme Cantal, J.A., 1998. A preliminary catalogue of Holocene equids from the Iberian Peninsula. In: Atti del XIII Congrès Union Internationale Sciences Prehistoriques et Protohistoriques - UISPP (Forli, Italia, 1996) (1998). Forli, vol. 6(1), pp. 65-81.

Nores, C., Liesau, C., 1992. La Zoologia historica como complemento de la Arqueozoologia. El caso del Zebro. Archaeofauna 1, 61-71.

Orlando, L., Mashkour, M., Burke, A., Douady, C.A., Eisenmann, V., Hänni, C., 2006. Geographic distribution of an extinct equid (Equus hydruntinus: Mammalia, Equidae) revealed by morphological and genetical analyses of fossils. Mol. Ecol. $15,2083-2093$.

Orlando, L., Metcalf, J.L., Alberdi, M.T., Telles-Antunes, M., Bonjean, D., Otte, M., Martin, F., Eisenmann, V., Mashkour, M., Morello, F., et al., 2009. Revising the recent evolutionary history of equids using ancient DNA. PNAS 106 (51), 21754-21759.

Pereira, F., Davis, S.J.M., Pereira, L., McEvoy, B., Bradley, D.G., Amorim, A., 2006. Genetic signatures of a Mediterranean influence in Iberian Peninsula sheep husbandry. Mol. Biol. Evol. 23 (7), 1420-1426.

Polzin, T., Daneschmand, S.V., 2003. On Steiner trees and minimum spanning trees in hypergraphs. Operations Res. Lett. 31, 12-20. 
Posada, D., 2008. jModelTest: phylogenetic model averaging. Mol. Biol. Evol. 25, $1253-1256$

Poyato Holgado, C., Hernando Grande, A., 1988. Relaciones entre la peninsula Ibérica y el Norte de África. "marfil y campaniforme". In: Ripoll Perelló, E. (Ed.), Congreso Internacional El Estrecho de Gibraltar (Ceuta, 1987), Proceedigs. 1. UNED Ayuntamiento de Ceuta, Madrid, pp. 317-329.

Rossel, S., Marshall, F., Peters, J., Pilgrim, T., Adams, M.D., O’Connor, D., 2008. Domestication of the donkey: timing, process, and indicators. PNAS 105 (10) 3715-3720.

Rowley-Conwy, P., 1993. Mesolithic animal bones from Forno da Telha, Portugal. In: Araújo, A.C. (Ed.), A estação mesolítica do Forno da Telha (Rio Maior), Primeiro Congresso de Arqueologia Peninsular (Porto, 1993). Actas. Porto: SPAE, vol. 1 pp. $45-50$.

Schubert, M., Ginolhac, A., Lindgreen, S., Thompson, J.F., Al-Rasheid, K.A.S., Willerslev, E., Krogh, A., Orlando, L., 2012. Improving ancient DNA read mapping against modern reference genomes. BMC Genomics 13, 178.

Schuhmacher, T.X., Banerjee, A., 2012. Procedencia e intercambio de marfil en el Calcolítico de la peninsula Ibérica. Rubricatum 5, 289-298.

Schuhmacher, T.X., Cardoso, J.L., Banerjee, A., 2009. Sourcing Africa ivory in Chalcolithic Portugal. Antiquity 83 (322), 983-997.
Silvestro, D., Michalak, I., 2012. raxmlGUI: a graphical front-end for RAxML. Org. Divers. Evol. 12, 335-337.

Stothard, P., 2000. The sequence manipulation suite: javascript programs for analyzing and formatting protein and DNA sequences. Biotechniques 28, 1102 1104.

Uerpmann, H.-P., 1976. Equus (Equus) caballus und Equus (Asinus) hydruntinus im Plestozän der Iberischen Halbinsel (Perissodactyla, Mammalia). Säugetierkundliche Mitteilungen 24, 206-218.

Valente, MJ., 2008. As últimas sociedades de caçadores-recolectores no centro e su de Portugal (10 000-6 000 BP): aproveitamento dos recursos animais. Universidade do Algarve, Faro (unpublished PhD thesis).

Vilstrup, J.T., Seguin-Orlando, A., Stiller, M., Ginolhac, A., Raghavan, M., Nielsen, S.C.A., Weinstock, J., Froese, D., Vasiliev, S.K., Ovodov, N.D., et al., 2013. Mitochondrial phylogenomics of modern and ancient equids. PLoS ONE 8 (2), e55950.

Von den Driesch, A., 2000. Revision zum Vorkommen des Equus (Asinus) hydruntinus (Regalia 1907) im Chalcolithikum der Iberischen Halbinsel. Archaeofauna 9, 35-38.

Xu, X., Gullberg, A., Arnason, U., 1996. The complete mitochondrial DNA (mtDNA) of the donkey and mtDNA comparisons among four closely related mammalian species-pairs. J. Mol. Evol. 43 (5), 438-446. 